\title{
Slow Outward Tail Currents in Molluscan Bursting Pacemaker Neurons: Two Components Differing in Temperature Sensitivity
}

\author{
S. Thompson, S. J. Smith, * and J. W. Johnson \\ Hopkins Marine Station, Stanford University, Pacific Grove, California 93950, and *Section of Molecular \\ Neurobiology, Yale Medical School, New Haven, Connecticut 06510
}

\begin{abstract}
Bursting pacemaker neurons of Tritonia and Aplysia were studied in voltage-clamp experiments to determine the ionic requirements of the slow outward tail current. This current is important for terminating bursts and hyperpolarizing the neuron during the interval between bursts and therefore contributes to the timing of pacemaker activity. A method for rapid extracellular perfusion of the neuron soma with solutions of different ionic composition was used to study the ionic dependence of the tail current. Measurements of the current-voltage relationship were made at different times during the decay of the tail current to determine the reversal potential in different ionic solutions. These experiments showed that 2 or more slow outward currents contribute to the tail current. Temperature had a large effect on these currents. At cold temperatures $\left(10-15^{\circ} \mathrm{C}\right)$, the tail current was predominantly a $\mathrm{K}$ current. At warm temperatures $\left(20-23^{\circ} \mathrm{C}\right)$, both a $K$ current and a $K$-insensitive outward current were seen. Bursting pacemaker activity occurred throughout this temperature range. Both the $K$ current and the $K$-insensitive current required $\mathrm{Ca}$ influx for activation. These findings help to reconcile conflicting reports in the literature concerning the ionic dependence of the slow outward tail current and suggest a mechanism for temperature compensation of bursting activity in these pacemaker cells.
\end{abstract}

The periodic bursts of action potentials produced by molluscan bursting pacemaker neurons depend on ionic currents that are active at voltages below spike threshold. In voltage-clamp experiments these currents appear as slowly relaxing tail currents after a depolarizing voltage-clamp pulse. Slow tail currents have been analyzed in a number of bursting pacemaker neurons, including Tritonia cells RP12, LP12, and LP13 (Smith, 1978; Smith and Thompson, 1986; Thompson, 1976) and Aplysia cells R15 (Adams, 1985; Adams and Levitan, 1985; Barker and Gainer, 1975; Carnevale and Wachtel, 1980; Gola, 1974; Gorman and Thomas, 1980; Gorman et al., 1982; Johnston, 1980; Lewis, 1984) and L2-L6 (Kramer and 7ucker, 1985a, b). These studies have led to plausible schemes for the generation and timing of bursting pacemaker activity that serve as models for other types of pacemaker cells in other organisms. A slowly decaying inward tail current is responsible for producing depolarizing afterpotentials following spikes and promotes repetitive firing during bursts (Lewis, 1984; Thompson and Smith,

\footnotetext{
Received Nov. 4, 1985; revised Apr. 7, 1986; accepted Apr. 17, 1986.

We thank Ms. F. Sommer of the Monterey Bay Aquarium for the gift of Tritonia specimens and Ms. J. Coombs-Hahn for helpful discussions. The drawings in Figure 1 are the work of F. Sommer. We also thank R. S. Zucker, R. H. Kramer, I. B. Levitan, and W. B. Adams for preprints of their work. The research was conducted at the Hopkins Marine Station of Stanford University, and we thank the staff of that institution and Ms. S. Nugent for help in the preparation of the manuscript. Research supported by NIH Grants NS14519 (S.T.), NS16671 (S.J.S.), and MH09113 (J.W.J.).

Correspondence should be addressed to Stuart Thompson at the above address. Copyright (C) 1986 Society for Neuroscience $0270-6474 / 86 / 113169-08 \$ 02.00 / 0$
}

1976). A slowly relaxing outward tail current causes adaptation in spike frequency during bursts and contributes toward burst termination and hyperpolarization of the membrane during the interburst interval.

Two different conclusions were drawn from these studies concerning the mechanism of the slow outward current. Several researchers found that it is a $K$ tail current that persists for more than $30 \mathrm{sec}$ after a depolarizing pulse and results from the decay of Ca-activated potassium current (Gola, 1974; Gorman et al., 1982; Johnston, 1980; Smith, 1978; Smith and Thompson, 1986; Thompson, 1976, 1977). Others found that the outward tail current is insensitive to the external $\mathrm{K}$ concentration, does not reverse near the expected $\mathrm{K}$ equilibrium potential, and, therefore, is not a $\mathrm{K}$ current. They suggested that the outward tail current may result from recovery of inward $\mathrm{Ca}$ current from inactivation (Adams and Levitan, 1985; Kramer and Zucker, 1985b). There exists, therefore, a discrepancy in the literature concerning the mechanism of the slow outward tail current. An understanding of the mechanism is fundamental to the analysis of burst generation in these pacemaker neurons.

We studied the ionic dependence and current-voltage relationship of slow outward tail currents in Tritonia bursters LP12 and LP13 and Aplysia cells R15, L2, L3, L4, and L6. A rapid extracellular perfusion method was used to determine the sensitivity of tail-current amplitude to changes in $\mathrm{K}$ and $\mathrm{Ca}$ concentration by applying solutions of different ionic composition directly to the voltage-clamped cell body membrane. A method for rapidly measuring the current-voltage relationship during the tail current was used to study changes in reversal potential following changes in external ion concentrations.

Changes in temperature have a strong effect on the slow outward tail current and show that 2 or more processes with different temperature sensitivities are involved. At cold temperatures $\left(10-15^{\circ} \mathrm{C}\right)$, the outward tail current is primarily a $\mathrm{K}$ current. When the preparation is warmed to $20-23^{\circ} \mathrm{C}$, the $\mathrm{K}$ current is still present but decays more quickly. At the warmer temperatures, an additional outward current that is insensitive to the external $\mathrm{K}$ concentration also makes a major contribution to the tail current. The $\mathrm{K}$-insensitive current decays much more slowly than the $\mathrm{K}$ current. This effect of temperature is seen in all of the bursting pacemaker cells, and bursting activity occurs throughout this temperature range.

The conclusion we draw from these studies is that 2 or more outward currents may contribute to hyperpolarizing the neuron during the interval between bursts. Temperature determines the proportion of the slow outward tail current that is contributed by $\mathrm{K}$ current and by $\mathrm{K}$-insensitive outward current.

\section{Materials and Methods}

\section{Preparation}

We studied pleural ganglion cells LP12 and LP13 of Tritonia (Willows et al., 1973; specimens kindly provided by Ms. Freya Sommer, Mon- 

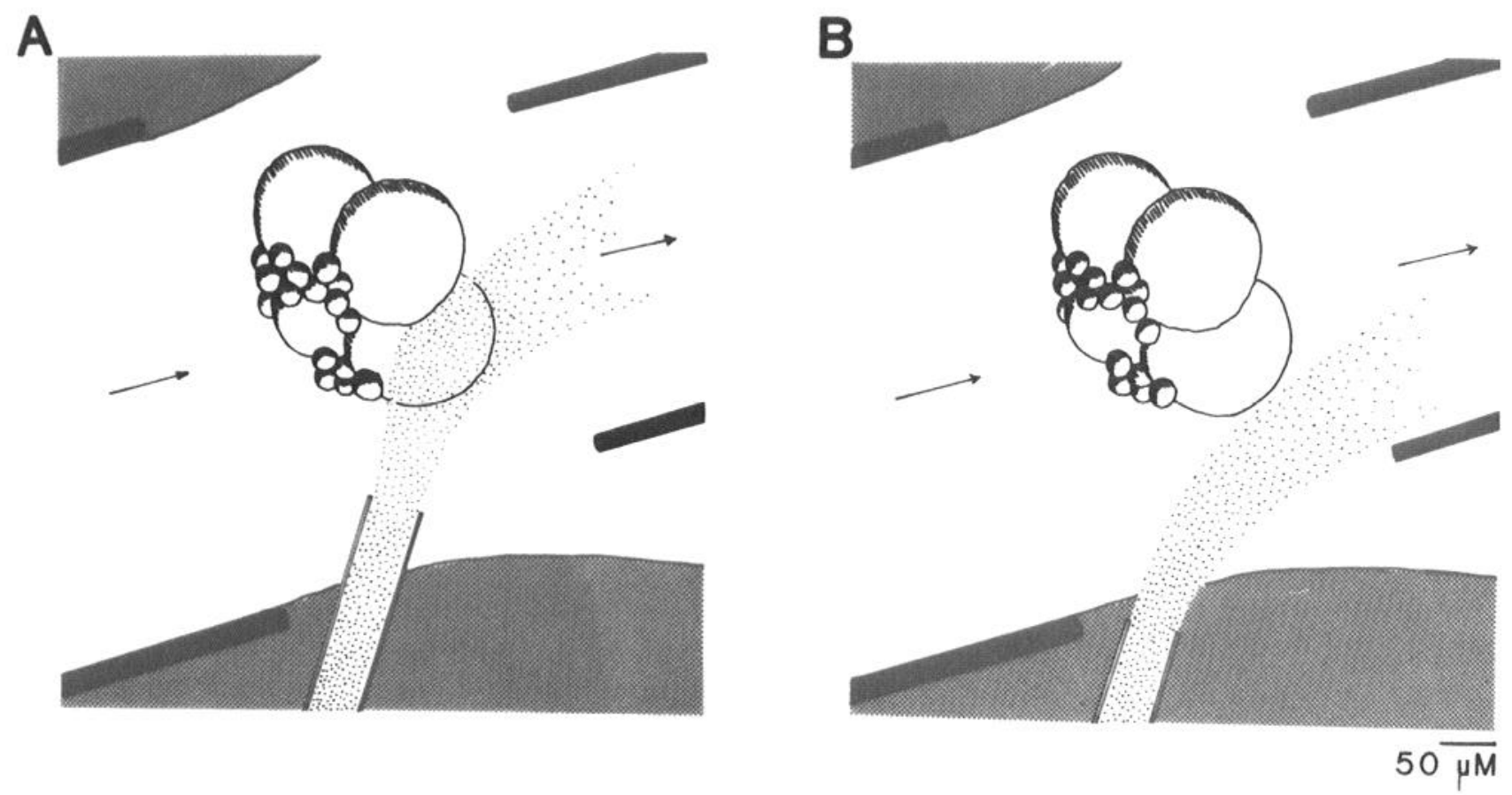

Figure 1. Extracellular microperfusion method. A, Diagram of the setup with the microperfusion pipette in the down position exposing the cell body of one neuron to the saline streaming from the pipette. $B$, Diagram showing the pipette in the up position so that the cell body is exposed to the bulk perfusion fluid.

terey Bay Aquarium, Monterey, CA) and abdominal ganglion cells R15, L2, L3, L4, and L6 of Aplysia (Frazier et al., 1967; specimens obtained from Sea Life Supply, Sand City, CA). The ganglia were removed from the animals and treated with neutral protease for $1 \mathrm{hr}$ (Dispase, Calbiochem; $0.5 \%$ solution) to soften the epineural sheath. Aplysia ganglia were desheathed by microdissection. The epineural sheath was left in place for the Tritonia ganglia. Aplysia cells L2, L3, L4, and L6 were partially axotomized by undercutting with iris scissors and removed from the ganglion for study. Aplysia cell R15 and the Tritonia neurons were left in place in the ganglia with the nerve roots cut short. Only cells showing fully developed bursting pacemaker activity after insertion of both microelectrodes were included in this study.

The preparation was transferred to a recording chamber designed to allow a continuous bulk flow of perfusate to be directed over the cells to a suction point directly opposite the inlet. Three bulk perfusion salines were used: (1) normal artificial seawater (NASW) $-470 \mathrm{~mm} \mathrm{NaCl}, 10$ mм KCl, $10 \mathrm{~mm} \mathrm{CaCl}_{2}, 50 \mathrm{~mm} \mathrm{MgCl}, 10 \mathrm{~mm}$ HEPES (pH 7.8); (2) low-Ca, $\mathrm{Mn}$ saline (MnSW) - same as NASW, except $\mathrm{CaCl}_{2}$ was lowered to $1 \mathrm{~mm}$ and $9 \mathrm{~mm} \mathrm{MnCl}$ was added; (3) Ca-free saline (0 Ca)-same as NASW except $5 \mathrm{~mm} \mathrm{CoCl}$ and $5 \mathrm{~mm} \mathrm{MgCl}_{2}$ replaced $\mathrm{CaCl}_{2}$. A microscope stage employing Peltier devices was used to control the temperature of the preparation to within $\pm 0.5^{\circ} \mathrm{C}$. Bath temperature was monitored by a calibrated thermistor probe (Yellow Springs Inst.), and the perfusion solutions were precooled to ensure good temperature control.

\section{Voltage-clamp and separation of currents}

Standard 2 microelectrode voltage-clamp techniques were used as described by Barish and Thompson (1983). Micropipettes were filled with $3 \mathrm{M} \mathrm{KCl}$ or $3 \mathrm{M} \mathrm{K}$-acetate and had resistances of 4-10 M 2 . The choice of anion had no effect on the currents we measured. Membrane voltage was measured between one of the micropipettes and an electrode in the bath. Membrane current was measured with either a virtual ground circuit or a voltage-clamp amplifier employing separate voltage-sensing and current-passing electrodes applied to the bath. All electrodes were $\mathrm{Ag}-\mathrm{AgCl}$ wires immersed in $3 \mathrm{M} \mathrm{KCl}, 3 \mathrm{~m} \mathrm{~K}$-acetate, or a NASW- $1 \%$ agar mixture. Records of slow tail currents were filterd at a corner frequency of $20 \mathrm{~Hz}$ and digitized by a laboratory computer system (DEC $11 / 23$ ) at a sampling rate of $500 \mathrm{~Hz}$.

The tail current on return to the holding voltage after a depolarizing voltage step is composed of several separate ionic currents. In this report we concentrate on the slowest components of the tail current. Fast $\mathrm{Na}$ and $\mathrm{Ca}$ currents decay quickly on repolarization to $-40 \mathrm{mV}$ and are not resolved at the filter setting used in these experiments (Adams and Gage, 1979; Byerly et al., 1985; Connor, 1977; Smith and Zucker, 1980). Similarly, the voltage-dependent delayed potassium current, $I_{\mathrm{K}}$, decays in less than $1 \mathrm{sec}$ after repolarization to $-40 \mathrm{mV}$ and does not contaminate the measurement of slow tail currents at later times (Thompson, 1977). A slow inward tail current that is characteristic of bursting pacemaker neurons is observed during the first $2-5 \mathrm{sec}$ after repolarization (Adams and Levitan, 1985; Gola, 1974; Kramer and Zucker, 1985a; Lewis, 1984; Smith, 1978; Smith and Thompson, 1986; Thompson, 1976). We separated the outward tail current from this slow inward tail current in the following ways. In the microperfusion experiments we measured the difference between tail currents recorded in 2 salines that differed in $\mathrm{K}$ concentration. Since the amplitude of the slow inward tail current does not depend on the external $\mathrm{K}$ concentration, it does not contribute to the difference current (Kramer and Zucker, 1985a; Smith, 1978; Thompson, 1976). When measuring $I-V$ curves, we started the measurement after the slow inward current had decayed to near zero amplitude.

\section{Extracellular microperfusion and solution changes}

A stream of saline from a glass pipette ( $50 \mu \mathrm{m}$ diameter) was used to apply solutions of different ionic composition directly to the neuron cell body. The pipette was micromanipulated into the flow of the bulk perfusion solution to expose the cell body to the stream from the pipette or moved out of the bulk flow to expose the cell body to the bulk solution as illustrated in Figure 1. The fluid in the pipette contained $1 \mathrm{~mm}$ phenol red so that the stream of saline could be seen and the pipette accurately positioned so its contents flowed only over the soma of the neuron under study or even over a restricted region of the soma. With this method the solution bathing the cell body could be changed in a few seconds. The pipette contained NASW, MnSW, or a high-K solution $(50$ or $100 \mathrm{~mm} \mathrm{~K}$ ) prepared by equimolar substitution of $\mathrm{KCl}$ for $\mathrm{NaCl}$ in NASW. The $\mathrm{pH}$ of all solutions was adjusted to 7.8. Control experiments using NASW plus $1 \mathrm{~mm}$ phenol red in the pipette showed that the dye had no effect on the parameters we measured.

The advantage of the microperfusion method is that only the soma of the neuron under study is exposed to high-K saline that could excite 
$A$

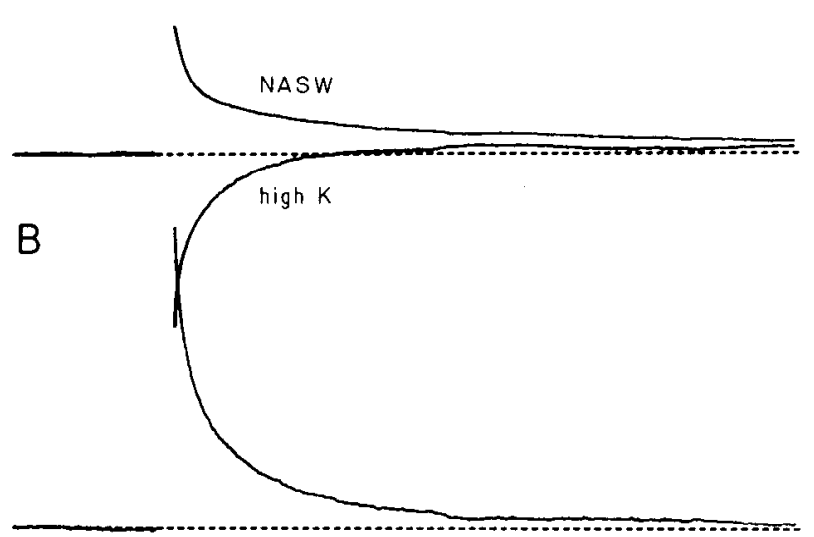

$5 n A$

$5 \mathrm{sec}$

Figure 2. Slow tail currents in Tritonia cell LP13 at $15^{\circ} \mathrm{C}, A$, Outward tail current on return to $-40 \mathrm{mV}$ after a $1 \mathrm{sec}$ pulse to $-10 \mathrm{mV}$ in NASW and during microperfusion of the soma with $100 \mathrm{~mm} \mathrm{~K}$ saline. $B$, Difference current calculated by subtracting the current in high $\mathrm{K}$ from the current in NASW. Difference current shows the time course of the $\mathrm{K}$ tail current that originates at the soma membrane. Dotted lines were drawn to show the steady-state holding current. All records from the same cell.

presynaptic tcrminals and causc local release of neurotransmitters or neuromodulators in the neuropil of the ganglion, effects that could complicate the analysis. The advantage of measuring the difference between currents recorded at $2 \mathrm{~K}$ concentrations is that currents originating in the axon, where voltage-clamp control may be poor, are subtracted and only currents originating at the cell body remain.

\section{Measurement of $\mathrm{I}-\mathrm{V}$ curves}

Current-voltage, $I(V)$, curves were measured during the outward tail current using the method described by Ruben et al. (1985). Membrane voltage was stepped through a staircase pattern beginning at $-40 \mathrm{mV}$ and progressing in $5 \mathrm{mV}$ increments to $-80 \mathrm{mV}$. Each step lasted 20 msec (see insert in Fig. 6). Membrane current was low-pass-filtered at $500 \mathrm{~Hz}$, digitized at $4 \mathrm{kHz}$, and recorded during this sequence of voltage steps. To reduce noise, $6-12 \mathrm{msec}$ of current data at each voltage were averaged. The average was begun after the capacitive current had settled, as described by Ruben et al. (1985). With this method, a 9-point $I(V)$ curve, which can resolve a change of less than $10 \%$ of the resting membrane conductance, can be generated in $180 \mathrm{msec}$. The advantage of this method is that $I(V)$ curves can he measured rapidly during a single tail current, so the result is not complicated by decay of the tail current during the measurement or by changes in tail-current amplitude during repeated measurements.

The $I(V)$ curve represents the sum of all of the individual ionic currents active at the time of the measurement. Since we were interested in the $I(V)$ curve that characterizes the slow outward tail current, a subtraction method was used to measure that current in isolation. A control $I(V)$ curve, measured before a depolarizing pulse, was subtracted point by point from the $I(V)$ curve measured during the outward tail current to yield a difference $I(V)$ curve. Any current not affected by the depolarization is eliminated by the subtraction. If the conductance change underlying the tail current is not voltage dependent or has slow kinetics, the difference $I(V)$ curve will resemble an instantaneous $I(V)$ curve for the tail current. The slope of the curve indicates whether there is a conductance increase (positive slope) or decrease (negative slope), and the point at which the curve crosses the voltage axis, if it does so, indicates the reversal potential of the current.

If the conductance underlying the tail current is voltage dependent and has rapid kinetics, so that it changes during the voltage steps used to measure the difference $I(V)$ curve, then the interpretation described above is not appropriate. Two important questions can be addressed

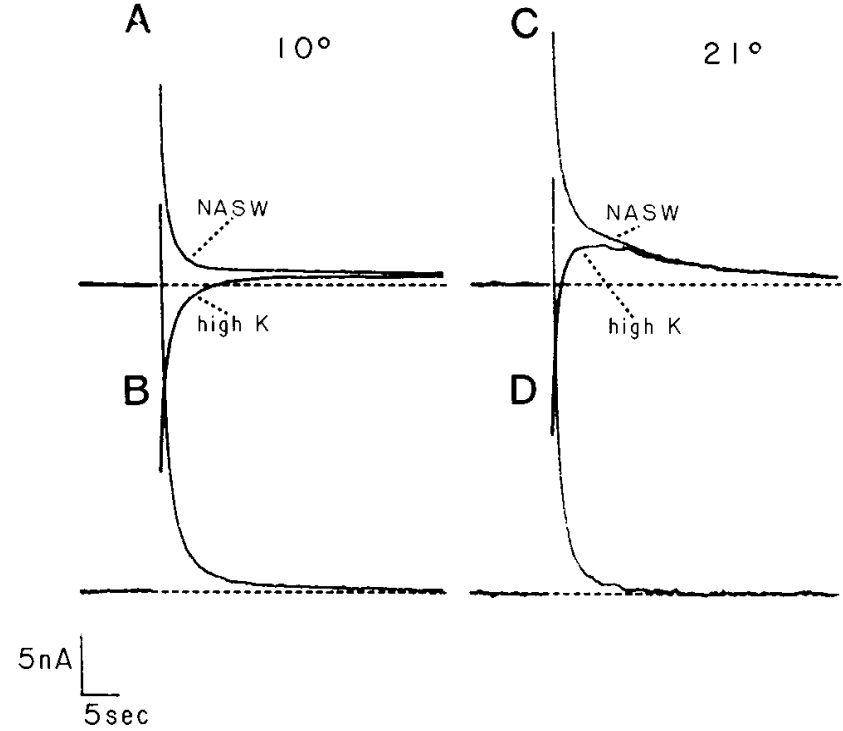

Figure 3. Tail currents at 10 and $21^{\circ} \mathrm{C}$ in Aplysia cell L2. Tail currents were activated by a $1 \mathrm{sec}$ depolarization to $-5 \mathrm{mV}$ and recorded on return to $-40 \mathrm{mV}$. $A$, Tail currents recorded in NASW and during microperfusion of the soma with $100 \mathrm{~mm} \mathrm{~K}$ saline at a temperature of $10^{\circ} \mathrm{C}$. $B$, Difference current showing the time course of $\mathrm{K}$ current originating at the soma at $10^{\circ} \mathrm{C}$. C, Tail currents in NASW and during microperfusion with $100 \mathrm{mM} \mathrm{K}$ saline after warming the preparation to $21^{\circ} \mathrm{C}$. $D$, Difference current showing the time course of somatic $\mathrm{K}$ current at the warmer temperature. All parts of the experiment were performed on a single neuron. Dotted lines show the steady-state holding current.

under these circumstances, however, by comparing difference $I(V)$ curves measured under different experimental conditions: (1) Is the entire tail current due to a change in one type of ionic conductance? If so, the amplitude of the current at each voltage should change when $I(V)$ curves are measured at different times during the decay of the tail current, but the shape of the curve and the apparent reversal potential should remain constant. (2) Is the tail current a $\mathrm{K}$ current? If it is, the reversal potential should be similar to reversal potentials measured for other K currents, and it should shift appropriately along the voltage axis when the external $\mathrm{K}$ concentration is changed.

\section{Results}

\section{Microperfusion experiments}

A prolonged lail current is seen when the membrane voltage is returned to the holding potential after a depolarizing pulse. Figure $2 A$ shows tail currents recorded from Tritonia bursting pacemaker cell LP13 at a temperature of $15^{\circ} \mathrm{C}$. In NASW the slow tail current after a $1 \mathrm{sec}$ pulse to $-10 \mathrm{mV}$ is outward at the -40 $\mathrm{mV}$ holding potential. During microperfusion of the soma with $100 \mathrm{~mm} \mathrm{~K}$ saline, the tail current is initially inward. The tail current in high $\mathrm{K}$ was subtracted point by point from the tail current in NASW to calculate a difference current that represents the time course of $\mathrm{K}$ tail current originating at the soma (Fig. $2 B$ ). These data show that a slow $\mathrm{K}$ current persists for more than $35 \mathrm{sec}$ after repolarization under these conditions.

The design of this experiment does not permit a quantitative measure of the $\mathrm{K}$ current because the microperfusion stream is directed over only a portion of the voltage-clamped membrane. Potassium tail current in soma, dendrite, and axon membrane that is not exposed to the stream of high-K saline will be outward at the $-40 \mathrm{mV}$ holding voltage and will sum with the current produced in the part of the soma that is exposed to high $\mathrm{K}$. The difference current illustrated in Figure $2 B$, therefore, underestimates the contribution madc by $\mathrm{K}$ current to the slow outward tail current. Smith and Thompson (1986) performed a similar 
A

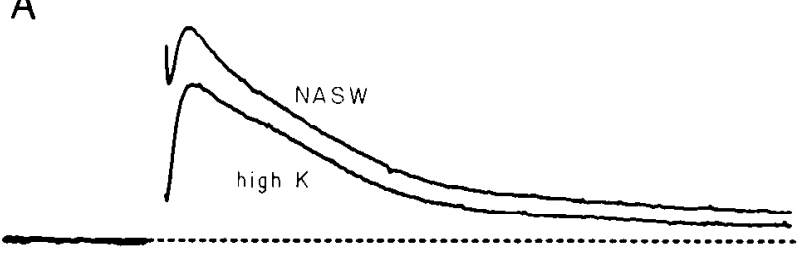

B

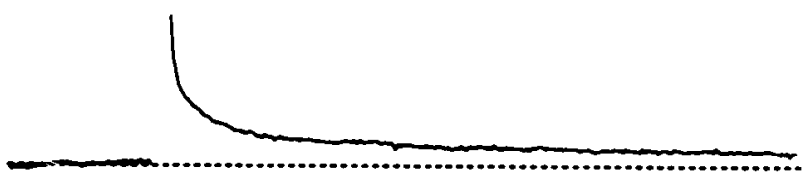

$4 n A \frac{}{5 \mathrm{sec}}$

Figure 4. Tail currents in Aplysia cell R 15 at $20^{\circ} \mathrm{C}$. Tail currents were activated by a $1 \mathrm{sec}$ depolarization to $-20 \mathrm{mV}$ and recorded on return to $-40 \mathrm{mV}$. A, Tail currents recorded while the cell was bathed in NASW and during microperfusion of only the very top of the soma, antipodal to the axon, with $100 \mathrm{~mm} \mathrm{~K}$ saline. $B$, Difference current showing the time course of $\mathrm{K}$ current originating in cell body membrane antipodal to the axon.

analysis of slow outward tail currents in Tritonia cell LP13 at a temperature of $10-11^{\circ} \mathrm{C}$. In those experiments the entire cell was exposed to both NASW and high-K saline, and the results showed that greater than $85 \%$ of the slow outward tail current was due to a $\mathrm{K}$ current.

\section{Effect of temperature}

Figure 3 shows tail currents recorded at 10 and $21^{\circ} \mathrm{C}$ from Aplysia cell L2. Tail currents were activated by depolarizing to -5 $\mathrm{mV}$ for $1 \mathrm{sec}$ and recorded on return to $-40 \mathrm{mV}$ both in NASW and during microperfusion of the soma with $100 \mathrm{~mm} \mathrm{~K}$ saline. The records taken at $10^{\circ} \mathrm{C}$ (Fig. $3, A, B$ ) are similar to those for the Tritonia cell in Figure 2. The difference current in Figure $3 B$ shows that a $\mathrm{K}$ current originating at the cell body makes a major contribution to the tail current for as long as $35 \mathrm{sec}$ after repolarization. In this example, a small fraction of the tail current does not invert when the cell body is exposed to high $\mathrm{K}$ (Fig. $3 A$ ). There are 2 reasonable explanations for this. Either a small fraction of the outward tail current is insensitive to $K$, or a region of the voltage-clamped membrane that is not exposed to high $\mathrm{K}$ during microperfusion of the soma contributes $\mathrm{K}$ current during the measurement.

When the preparation is warmed to $21^{\circ} \mathrm{C}$, the slow outward tail current in NASW is larger and it decays more gradually (Fig. 3C). During microperfusion of the cell body with $100 \mathrm{~mm}$ $\mathrm{K}$ saline, only the early part of the tail current is inverted, and at later times the tail current appears to be insensitive to the change in external $\mathrm{K}$ concentration. The difference between the tail currents recorded in NASW and during exposure to high K at $21^{\circ} \mathrm{C}$ shows that a $\mathrm{K}$ tail current lasts for about $16 \mathrm{sec}$ after repolarization (Fig. 3D). The $\mathrm{K}$ tail current has about the same amplitude as it had at the lower temperature, but it decays more quickly, reaching $1 / 5$ of its initial amplitude in $2.5 \mathrm{sec}$ at $21^{\circ} \mathrm{C}$ compared to $5 \mathrm{sec}$ at $10^{\circ} \mathrm{C}$. It is evident from these experiments that both a $\mathrm{K}$ current and an outward current that is insensitive to $\mathrm{K}$ contribute to the tail current at $21^{\circ} \mathrm{C}$. The $\mathrm{K}$-insensitive tail current has a much greater amplitude at $21^{\circ} \mathrm{C}$ than at $10^{\circ} \mathrm{C}$, and it decays more slowly than the $\mathrm{K}$ current.

Results similar to these were obtained over a wide range of
A

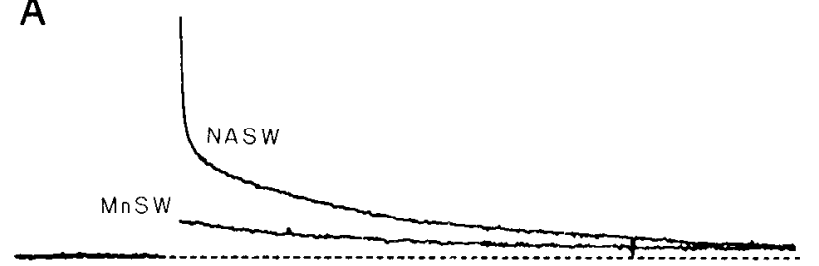

B

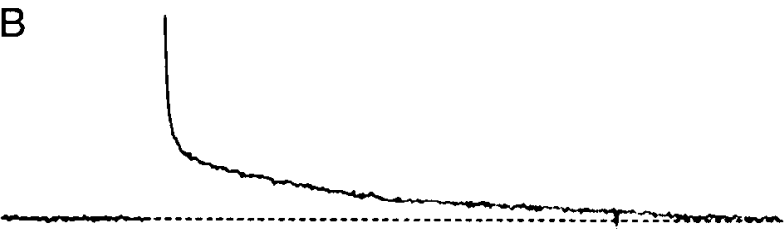

Figure 5. Effect of $\mathrm{Ca}$ applied at the soma on outward tail current; Aplysia cell L2 at $21^{\circ} \mathrm{C}$. The bath solution was $\mathrm{MnSW}(9 \mathrm{~mm} \mathrm{Mn}, 1$ mM Ca), while the microperfusion pipette contained NASW (10 mM Ca). Tail currents were activated by a $1 \mathrm{sec}$ depolarization to $-10 \mathrm{mV}$ and recorded on return to $-40 \mathrm{mV}$. $A$, Tail currents recorded in MnSW and during microperfusion of the soma with NASW. $B$, The Ca difference current calculated by subtracting the current in MnSW from the current recorded during microperfusion with NASW. Difference current shows the time course of the Ca-dependent tail current originating at the cell body. Dotted lines show the steady-state holding current.

activating pulse amplitudes and durations and at a number of intermediate temperatures in each of the cells, and the preparations could be repeatedly warmed and cooled with consistent results. An example using Aplysia cell R15 at a temperature of $20^{\circ} \mathrm{C}$ is shown in Figure 4. Tail currents were recorded at -40 $\mathrm{mV}$ after a $1 \mathrm{sec}$ depolarization to $-20 \mathrm{mV}$ in NASW and during microperfusion of the soma with $100 \mathrm{~mm} \mathrm{~K}$ saline (Fig. $4 A$ ). In this experiment, the stream of high $\mathrm{K}$ was directed over the very top of the soma of R15, antipodal to its axon. The amplitude of the outward tail current was decreased in high K, but the tail current remained outward, probably because only a small area of the cell body was exposed to high $\mathrm{K}$ while the rest of the soma, axon, and dendritic membrane was bathed in NASW. The difference current in Figure $4 B$ shows the time course of the $\mathrm{K}$ tail current originating at the top of the soma. The $\mathrm{K}$ current lasts longer than $40 \mathrm{sec}$ after repolarization.

The tail currents in Figure $4 A$ have complicated waveforms. At times earlier than $2 \mathrm{sec}$ after repolarization there is a notch of relatively inward current. This has been shown to be due to a slow inward tail current that is superimposed upon the outward tail current (Adams and Levitan, 1985; Gola, 1974; Kramer and Zucker, 1985a; Lewis, 1984; Smith, 1978; Thompson, 1976). The notch of inward current does not appear in the $K$ difference current in Figure $4 B$, showing that the subtraction method is capable of separating these currents.

The $\mathrm{K}$ tail current and the K-insensitive tail current respond in qualitatively different ways to changes in temperature. When the preparation is warmed from 10 to $20^{\circ} \mathrm{C}$ the amplitude of the total outward tail current, measured $5 \mathrm{sec}$ after repolarization, increases by an average factor of $2.14( \pm 0.47 \mathrm{SD} ; n=9)$. The amplitude of the $\mathrm{K}$ component of the tail current at this time, however, decreases by an average factor of $0.64( \pm 0.37$ $\mathrm{SD} ; n-9)$. This decrease is largely due to the more rapid decay of $\mathrm{K}$ current at the warmer temperature. From these observations it appears that the amplitude of the $\mathrm{K}$-insensitive tail current must increase by a factor greater than 3.3 for this $10^{\circ} \mathrm{C}$ increase in temperature. This high sensitivity to temperature 

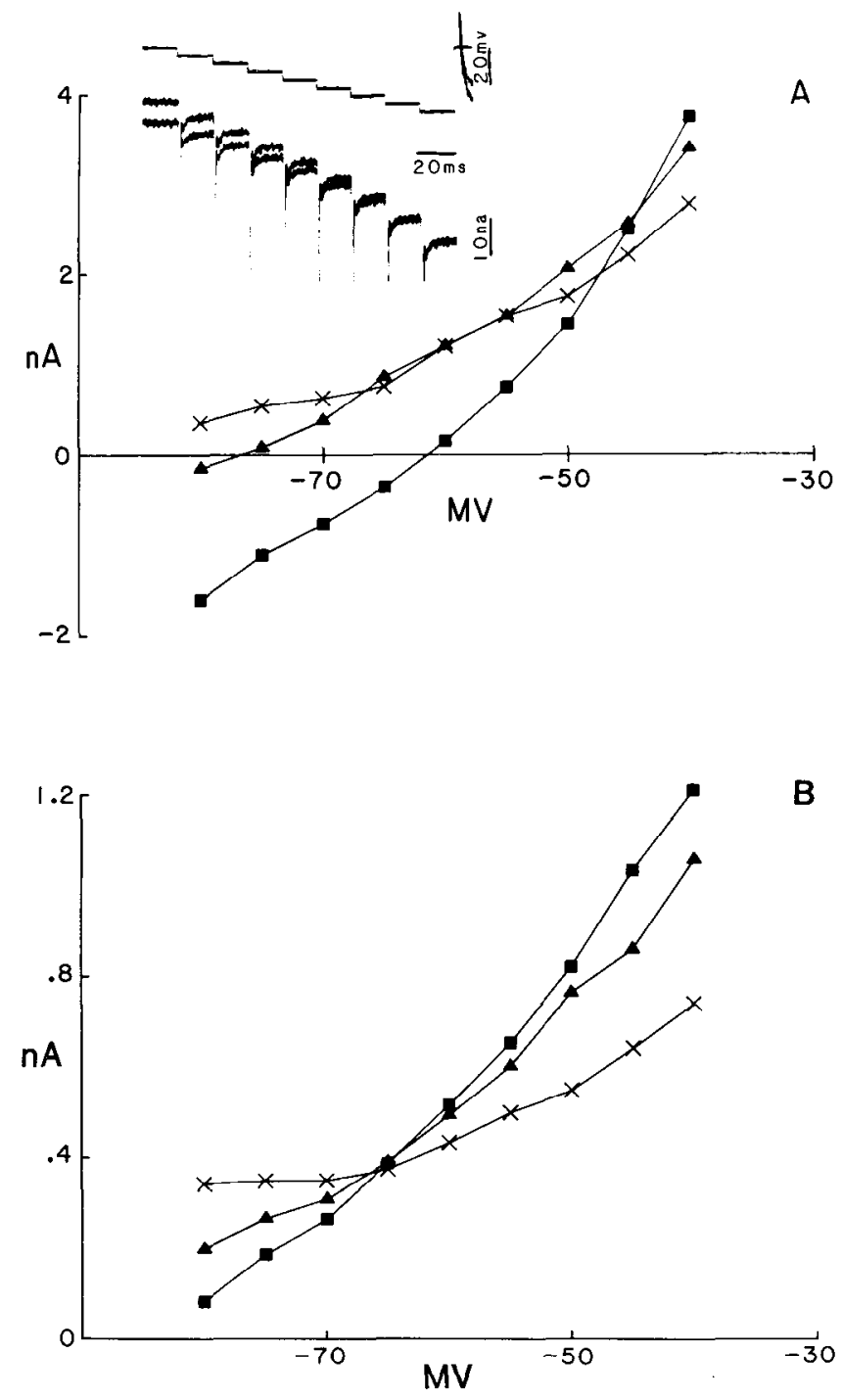

Figure 6. Difference $I(V)$ curves measured at various times during the slow outward tail current in Aplysia cell L2. Tail current was activated by a $0.5 \mathrm{sec}$ depolarization to $-10 \mathrm{mV}$ in NASW, and $I(V)$ curves were measured $2 \mathrm{sec}(\boldsymbol{D}), 5 \mathrm{sec}(\boldsymbol{\Lambda})$, and $10 \mathrm{sec}(\mathrm{x})$ after repolarization to -40 $\mathrm{mV}$. Difference $I(V)$ curves were calculated using the procedures described in Materials and Methods. Inset, Example of the raw data used in constructing difference $I(V)$ curves. $A$, Difference $I(V)$ curves measured at $12^{\circ} \mathrm{C}$. $B$, Difference $I(V)$ curves measured after warming the preparation to $22^{\circ} \mathrm{C}$. All measurements from the same cell.

suggests that the current might result from electrogenic active transport. We did not pursue this idea in detail but found that the tail current at $21^{\circ} \mathrm{C}$ is not affected by treatment with strophanthidin ( $50 \mu \mathrm{M}$ for $1 \mathrm{hr}$ ) and, therefore, probably does not result from activation of the Na,K-APTase (Thomas, 1972). This observation is in agreement with experiments reported by Kramer (1984).

Both the $\mathrm{K}$ tail current and the $\mathrm{K}$-insensitive tail current require extracellular $\mathrm{Ca}$ for their expression. Two experimental observations led to this conclusion. In the first kind of experiment, the cell was continuously perfused with a bulk solution that strongly reduced the Ca current (MnSW; $9 \mathrm{~mm} \mathrm{Mn,} 1 \mathrm{mN}$ Ca). Following a $1 \mathrm{sec}$ depolarization to $-10 \mathrm{mV}$, a small outward tail current was seen in this solution, as illustrated for Aplysia cell L2 at $21^{\circ} \mathrm{C}$ in Figure $5 A$. Microperfusion of the cell body with NASW (10 mM Ca) caused an increase in the amplitude of the outward tail current. The difference between the tail current recorded during microperfusion with NASW and during exposure to $\mathrm{MnSW}$ shows the time course of the $\mathrm{Ca}$ sensitive current that originates at the soma (Fig. $5 B$ ). This experiment was repeated at different extracellular $\mathrm{K}$ concentrations, and it was found that the amplitudes of both the $\mathrm{K}$ tail current and the $K$-insensitive tail current were enhanced by cxposing the cell body to $\mathrm{Ca}$. In a sccond kind of cxpcriment, the bulk perfusion saline was NASW while the microperfusion saline was MnSW. When the cell body was microperfused with MnSW, the amplitudes of both components of the outward tail current were reduced. Our interpretation of these experiments is that $\mathrm{Ca}$ influx is required for the expression of the $\mathrm{K}$ current and the $\mathrm{K}$-insensitive current and that both currents originate, at least in part, at the cell body.

\section{Current-voltage curves}

Difference current-voltage curves were measured at various times during the outward tail current using the procedures described in Materials and Methods. An example of the raw data used in constructing such curves is shown in the insert in Figure 6 . The results of these experiments support the conclusions resulting from the microperfusion experiments. Figure $6 \mathrm{~A}$ shows difference $I(V)$ curves for Aplysia cell L2 in NASW at $12^{\circ} \mathrm{C}$. The outward tail current was activated by a $0.5 \mathrm{sec}$ pulse to -10 $\mathrm{mV}$, and $I(V)$ curves were measured 2,5 , and $10 \mathrm{sec}$ after repolarization to $-40 \mathrm{mV}$. The difference $I(V)$ curve 2 sec after repolarization has a positive slope, a small curvature, and crosses the voltage axis at a reversal potential of $-62 \mathrm{mV}$. These data suggest that the tail current at this time is primarily due to a conductance increase to $\mathrm{K}$. The fact that the $I(V)$ curve crosses the voltage axis at $-62 \mathrm{mV}$ is of particular importance. This is not possible for an outward tail current due solely to recovery of $\mathrm{Ca}$ current from inactivation because a decrease in Ca current cannot result in inward current in the difference $I(V)$ curve at any voltage more negative than the $\mathrm{Ca}$ reversal potential.

The difference $I(V)$ curves measured 5 and $10 \mathrm{sec}$ after repolarization are somewhat different than the curve at $2 \mathrm{sec}$. These $I(V)$ curves tend to level off, and approach a reversal potential only at very negative voltages. These data suggest that another current that is not a $\mathrm{K}$ current makes an increasing contribution to the tail current at later times after repolarization. The $I(V)$ curve measurements are not helpful in identifying the conductance changes responsible for this additional current, but they show that the tail current measured at $12^{\circ} \mathrm{C}$ is not due to a single ionic current process with a unique reversal potential. Instead, the tail current must represent the sum of 2 or more ionic currents with different reversal potentials.

The preparation was warmed to $22^{\circ} \mathrm{C}$, and the measurements of difference $I(V)$ curves 2,5 , and $10 \mathrm{sec}$ after repolarization were repeated (Fig. $6 B$ ). These $I(V)$ curves show the same trend that was seen at $12^{\circ} \mathrm{C}$; flattening of the curve at negative voltages as the interval before measurement is increased. The progressive change in the difference $I(V)$ curve with time again shows that more than one ionic current contributes to the tail current. At the warm temperature, however, the current that does not reverse at negative potentials makes a greater contribution to the tail current than it does at $12^{\circ} \mathrm{C}$, especially at later times after repolarization.

The effect of external $\mathrm{K}$ on difference $I(V)$ curves was studied in salines containing 10 and $50 \mathrm{~mm} \mathrm{~K}$ at $12^{\circ} \mathrm{C}$. In these experiments, the $\mathrm{K}$ concentration of the solution bathing the entire cell was changed. Difference $I(V)$ curves measured $2 \mathrm{sec}$ after repolarization are shown in Figure $7 A$ for Aplysia cell L2. The reversal potential for the tail current changes from $-64 \mathrm{mV}$ in $10 \mathrm{~mm} \mathrm{~K}$ to $-39 \mathrm{mV}$ in $50 \mathrm{~mm} \mathrm{~K}$. This compares favorably with the change in reversal potential for the transient $K$ current, $I_{\mathrm{A}}$, measured in the same experiment $\left(I_{\mathrm{A}}\right.$ reversal potential $=$ $-67 \mathrm{mV}$ in $10 \mathrm{~mm} \mathrm{~K}$ and $-38 \mathrm{mV}$ in $50 \mathrm{~mm} \mathrm{~K}$ ). This exper- 

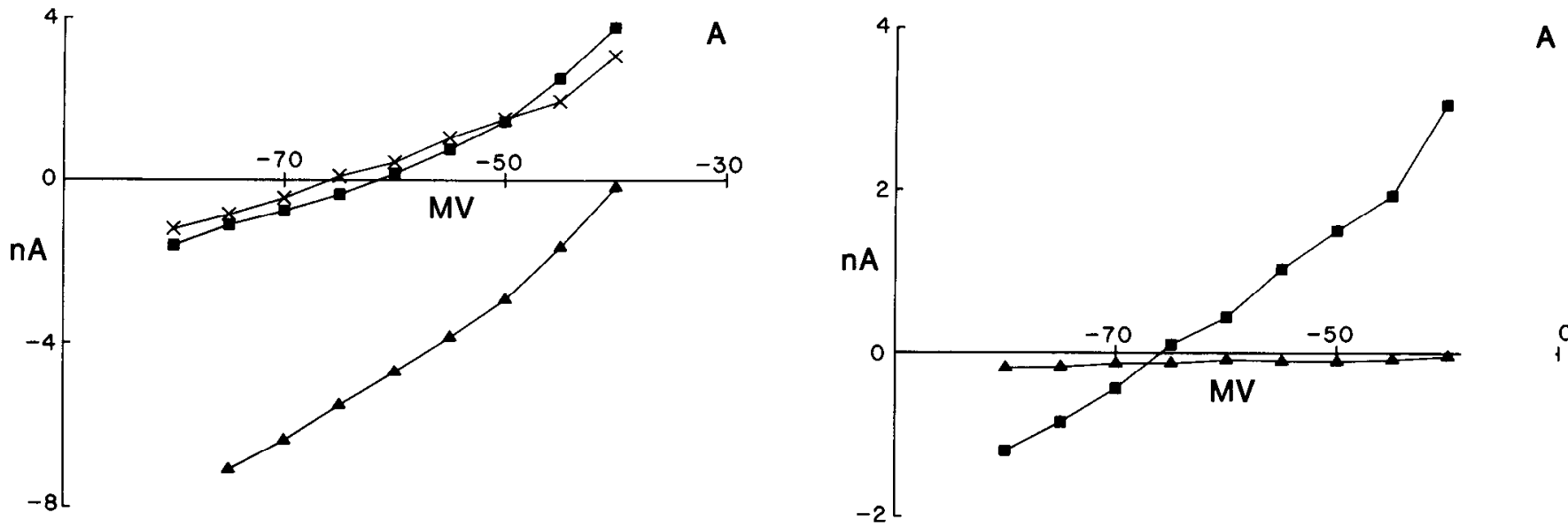

A

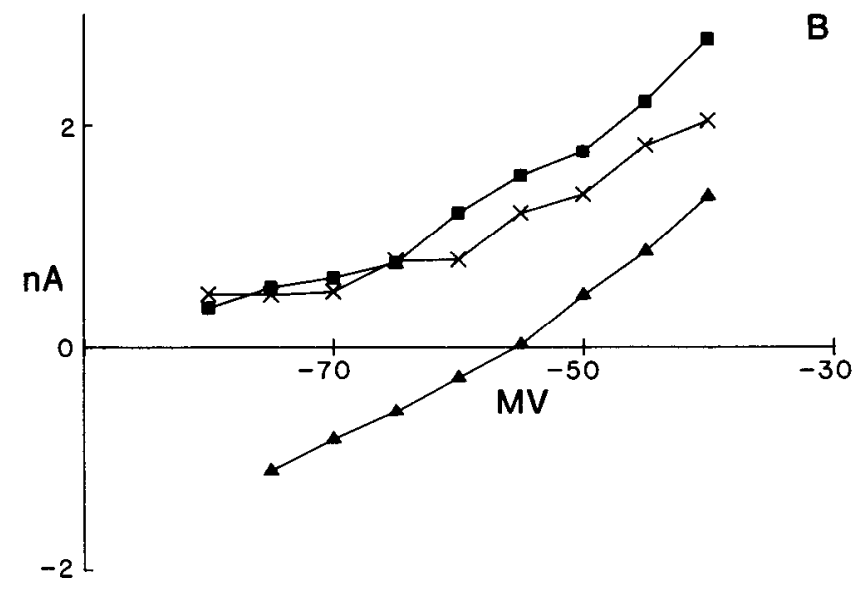

Figure 7. Difference $I(V)$ curves recorded at 2 external $\mathrm{K}$ concentrations. Tail currents were activated by a $0.5 \mathrm{sec}$ depolarization to -10 $\mathrm{mV}$ in Aplysia cell $\mathrm{L} 2$ at a recording temperature of $12^{\circ} \mathrm{C} . I(\mathrm{~V})$ curves were measured at different times after repolarizing to $-40 \mathrm{mV}$ in 10 $\mathrm{mm} \mathrm{K}(\square), 50 \mathrm{~mm} \mathrm{~K}(\Delta)$, and after return to $10 \mathrm{~mm} \mathrm{~K}(\mathrm{x})$. A, Difference $I(V)$ curves measured $2 \mathrm{sec}$ after repolarization. $B$, Difference $I(V)$ curves measured $10 \mathrm{sec}$ after repolarization. All measurements are from the same cell. Solution changes were made by changing the bath solution.

iment shows that the dominant conductance change $2 \mathrm{sec}$ after repolarization is a conductance increase to $K$.

The difference $I(V)$ curves measured $10 \mathrm{sec}$ after rcpolarization are shown in Figure $7 B$. In $10 \mathrm{~mm} \mathrm{~K}$ the current at 10 sec does not approach a reversal potential at negative voltages, but in $50 \mathrm{~mm} \mathrm{~K}$ there is a reversal of current at $-55 \mathrm{mV}$. The results indicate that $10 \mathrm{sec}$ after repolarization an increased conductance to $\mathrm{K}$ still contributes to the outward tail current. Part of the tail current is clearly insensitive to the change in external $\mathrm{K}$, however, and it is apparent that this component makes a greater relative contribution late in the tail current.

The effect of external $\mathrm{Ca}$ on difference $I(V)$ curves measured $2 \mathrm{sec}$ after repolarization is shown in Figure 8. $I(V)$ curves were measured in NASW and in $0 \mathrm{Ca}$ saline at $12^{\circ} \mathrm{C}$ (Fig. $8 \mathrm{~A}$ ) and $22^{\circ} \mathrm{C}$ (Fig. $8 B$ ). In $0 \mathrm{Ca}$ saline, the difference $I(V)$ curves at high and low temperatures are nearly flat, showing that external $\mathrm{Ca}$ is required for expression of both the $\mathrm{K}$ tail current and the $\mathrm{K}$ insensitive tail current.

\section{Discussion}

The conclusion drawn from the extracellular microperfusion experiments and $I(V)$ curve measurements is that a $\mathrm{K}$ current

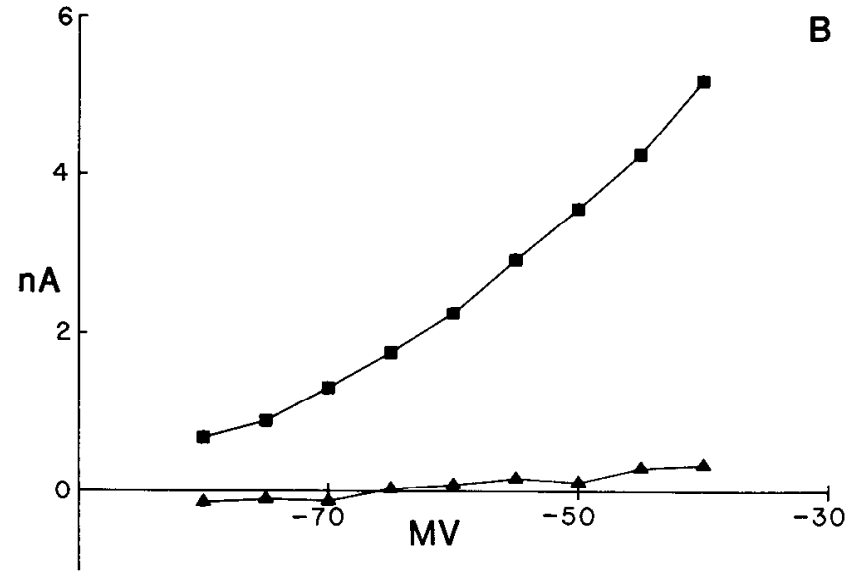

Figure 8. Effect of $\mathrm{Ca}$ on difference $I(V)$ curves. Tail currents were activated by a $0.5 \mathrm{sec}$ pulse to $-10 \mathrm{mV}$ in NASW (D) and in $0 \mathrm{Ca}$ saline $(\Delta)$ in Aplysia cell L2. Difference $I(V)$ curves were measured $2 \mathrm{sec}$ after repolarization at 2 recording temperatures. $A$, Difference $I(V)$ curves measured at $12^{\circ} \mathrm{C}$. $B$, Difference $I(V)$ curves measured after warming the preparation to $22^{\circ} \mathrm{C}$. Solution changes made by changing the bath solution.

and a $\mathrm{K}$-insensitive current both contribute to the slow outward tail current after depolarizing pulses in bursting pacemaker neurons of Tritonia and Aplysia. Both currents may be present at temperatures between 10 and $23^{\circ} \mathrm{C}$, but the relative contribution of each depends on the recording temperature. At cold temperatures, the outward tail current is predominantly a K current, whereas at warmer temperatures, the $\mathrm{K}$-insensitive current makes an increasingly important contribution to the tail current at later times after repolarization.

Our data suggest that the discrepency in the literature concerning the mechanism of the slow outward tail current may be resolved by the observation that the different investigators used different recording temperaturcs in thcir experiments. Those who concluded that the outward tail current was due to the decay of a K current used cold temperatures (Gola, $1974: 15^{\circ} \mathrm{C}$; Gorman et al., $1982: 15^{\circ} \mathrm{C}$; Smith, 1978: $10-11^{\circ} \mathrm{C}$; Smith and Thompson, 1986: $10-11^{\circ} \mathrm{C}$; Thompson, $1976: 10-11^{\circ} \mathrm{C}$ ). Those who found that the slow outward tail current was largely insensitive to the external $\mathrm{K}$ concentration used warm temperatures (Adams and Levitan, $1985: 21^{\circ} \mathrm{C}$; Kramer and Zucker, $1985 \mathrm{~b}$ : $23^{\circ} \mathrm{C}$; Lewis, $1984: 21^{\circ} \mathrm{C}$ ).

The $\mathrm{K}$ tail current requires extracellular $\mathrm{Ca}$ for its activation. 
On the basis of numerous studies by ourselves and others (for review, see D. J. Adams el al., 1980; Meech, 1978), we conclude that it represents the decay of the Ca-dependent potassium current, $I_{\mathrm{C}}$. The amplitude of $I_{\mathrm{C}}$ increases during depolarization due to the accumulation of $\mathrm{Ca}$ in the cytoplasm following the activation of voltage-dependent $\mathrm{Ca}$ channels. On repolarization, Ca channels close rapidly and $I_{\mathrm{C}}$ decays back to a low basal level as $\mathrm{Ca}$ slowly redistributes in the cytoplasm, becomes sequestered into cytoplasmic organelles, and is actively extruded from the cell. Because the activation of $I_{\mathrm{C}}$ depends on intracellular $\mathrm{Ca}$, its decay time course reflects the time course of the intracellular $\mathrm{Ca}$ concentration transient. The results described here show that the tail current due to $I_{C}$ decays more rapidly at warmer temperatures, possibly because the intracellular $\mathrm{Ca}$ concentration recovers more quickly.

The $\mathrm{K}$-insensitive outward tail current also requires extraccllular Ca for its cxpression (scc also Adams and Levitan, 1985; Kramer and Zucker, 1985b). This current decays more slowly than $I_{\mathrm{C}}$ at warm temperatures $\left(20-21^{\circ} \mathrm{C}\right)$. This finding explains the observation made by Barish and Thompson (1983) that, in nonbursting molluscan neurons, the rate of decay of slow outward tail current decreases with warming. We now know that as the preparation is warmed, a $\mathrm{K}$-insensitive current increases in amplitude and since it decays more slowly than $I_{\mathrm{C}}$, the rate of decay of the total outward tail current decreases.

We were not able to identify the $\mathrm{K}$-insensitive tail current in our experiments, and we do not know if it represents a single current process or several separate processes. Adams and Levitan (1985) and Kramer and Zucker (1985b) suggested that the slow outward tail current at warm temperatures results from the gradual recovery of $\mathrm{Ca}$ current from inactivation. In bursting pacemaker neurons, $\mathrm{Ca}$ current is partially activated at subthreshold voltages (Eckert and Lux, 1976; Kramer and Zucker, 1985a; Smith and Thompson, 1986). The increase in intracellular Ca concentration during depolarization could cause $\mathrm{Ca}-$ dependent inactivation of this current (Eckert and Tillotson, 1981; Tillotson, 1979; Tillotson and Horn, 1978; for review, see Eckert and Chad, 1984). The gradual recovery of Ca current from inactivation could produce a slow outward tail current as the internal $\mathrm{Ca}$ concentration gradually decreases after a depolarizing pulse. The time course of the outward tail current generated in this way would, once again, reflect the time course of recovery of the cytoplasmic $\mathrm{Ca}$ concentration transient. The results of our experiments are not inconsistent with this interpretation. We were unable to test this hypothesis, however, because we could not measure membrane current with sufficiently high signal-to-noise ratio and high bandwidth to resolve the inward tail current due to the closing of voltage-dependent Ca channels. This is a particularly difficult measurement because Ca current kinetics are fast at negative voltages, especially at warm temperatures, and only a small fraction of the conductance remains active late in the tail current (Byerly et al., 1985; Connor, 1977; Eckert and Ewald, 1982; Smith and Zucker, 1980). The changes in the $I(V)$ curve with increasing time after repolarization that we observed might be explained by a slow increase in $\mathrm{Ca}$ current during recovery from inactivation, but because of the rapid voltage-dependent kinetics of the $\mathrm{Ca}$ current, our data are not sufficient to demonstrate this phenomenon.

Both the activation of $I_{C}$ and the inactivation of Ca current are thought to depend on the concentration of $\mathrm{Ca}$ ions at the inner surface of the membrane. If we entertain the hypothesis that these 2 processes are solely responsible for the slow outward tail current, we must ask how it is possible that they have different kinetics and depend differently on temperature. Kramer and Zucker (1985b) suggested that interaction with 2 or more $\mathrm{Ca}$ ions may be needed to open $I_{\mathrm{C}}$ channels, while $\mathrm{Ca}$ current inactivation might only require interaction with a single $\mathrm{Ca}$ ion. According to this view, the activation of $I_{\mathrm{C}}$ would be more steeply dependent on the internal Ca concentration than the inactivation of $\mathrm{Ca}$ current. $I_{\mathrm{C}}$ would therefore be expected to decay more rapidly than $\mathrm{Ca}$ current inactivation as the intracellular $\mathrm{Ca}$ concentration recovers after a depolarizing pulse. The data concerning the stoichiometry of $I_{\mathrm{C}}$ activation and $\mathrm{Ca}$ current inactivation needed to evaluate this hypothesis are not yet available. An important deficiency of the hypothesis that should be pointed out is that it does not explain why the amplitude of $I_{r}$ decreases with warming, while the amplitude of the K-insensitive current increases. Since the amplitudes of both currents are thought to depend directly on the intracellular $\mathrm{Ca}$ concentration, a change in the rate of rccovcry of $\mathrm{Ca}$ concentration with warming would be expected to affect the amplitudes of both currents in the same way. This is not observed.

Other possible mechanisms for the $\mathrm{K}$-insensitive tail current include a metabolic reaction with a high temperature coefficient. For example, the current might result from a strophanthidinresistant electrogenic active transport process that is activated by $\mathrm{Ca}$. Alternatively, it might result from ionic currents originating in the axon or dendrites of the cells whose properties are distorted by poor potential control in those regions. An argument against this interpretation is that the results of the microperfusion experiments show that at least part of this current is generated in the cell body where voltage control is good.

Our results indicate that both a $\mathrm{K}$ current and a $\mathrm{K}$-insensitive current contribute to the outward tail current at warm temperatures and that both decay slowly after repolarization. Both currents would seem to be important for terminating bursts and for hyperpolarizing the cell during the interburst interval, and both would have to be included in models for burst generation at warm temperatures. When experiments are conducted at cold temperatures, the $\mathrm{K}$ current is predominantly responsible for the slow outward tail current. Thompson (1976) and Smith (1978) have shown that an outward current with the properties of the slow $K$ tail current is sufficient for modeling bursting pacemaker activity in Tritonia neurons at $10-11^{\circ} \mathrm{C}$, a temperature that approximates that of Tritonia's normal habitat.

All of the cells we studied generate bursting pacemaker activity at temperatures between 10 and $23^{\circ} \mathrm{C}$. In a study of Tritonia bursters, Anderson (1976) found that the rate at which bursts are produced is relatively insensitive to temperature, suggesting that burst frequency may be temperature compensated. The ability of poikilothermic animals to survive at different temperatures must require a variety of adapting mechanisms. This would appear to be particularly important for animals like Aplysia that enter the intertidal during certain seasons where they encounter large temperature fluctuations. Bursting pacemaker neurons may provide an example in which temperature compensation of cellular activity is accomplished by ionic mechanisms. The slow outward tail current contributes importantly to the timing of bursts. Temperature compensation of burst frequency may come about through a temperature-dependent gradation in the relative contribution of different ionic currents, which produce outward current during the interburst interval and influence the timing of bursts.

\section{References}

Adams, D. J., and P. W. Gage (1979) Characteristics of sodium and calcium conductance changes produced by membrane depolarization in an Aplysia neurone. J. Physiol. (Lond.) 289: 143-161.

Adams, D. J., S. J. Smith, and S. H. Thompson (1980) Ionic currents in molluscan soma. Annu. Rev. Neurosci. 3: 141-167.

Adams, W. B. (1985) Slow depolarizing and hyperpolarizing currents which mediate bursting in Aplysia neurone K15. J. Physiol. (Lond.) 360: 51-68.

Adams, W. B., and I. B. Levitan (1985) Voltage and ion dependences of the slow currents which mediate bursting in Aplysia neurone R15. J. Physiol. (Lond.) 360: 69-93. 
Anderson, W. W. (1976) Endogenous bursting in Tritonia neurons at low temperature. Brain Res. 103: 407-411.

Barish, M. E., and S. H. Thompson (1983) Calcium buffering and slow recovery kinetics in molluscan neurons. J. Physiol. (Lond.) 337: 201219.

Barker, J. L., and H. Gainer (1975) Studies on bursting pacemaker potential activity in molluscan neurons. I. Membrane properties and ionic contributions. Brain Res. 84: 461-477.

Byerly, L., P. Bryant-Chase, and J. R. Stimers (1985) Permeation and interaction of divalent cations in calcium channels of snail neurons. J. Gen. Physiol. 85: 491-518.

Carnevale, N. T., and H. Wachtel (1980) Two reciprocating current components underlying the slow oscillations in Aplysia bursting neurons. Brain Res. Rev. 2: 45-68.

Connor, J. A. (1977) Time course separation of two inward currents in molluscan neurons. Brain Res. 119: 487-492.

Eckert, R., and J. E. Chad (1984) Inactivation of Ca channels. Prog. Biophys. Mol. Biol. 44: 215-267.

Eckert, R., and D. Ewald (1982) Residual calcium ions depress activation of calcium-dependent current. Science 216: 730-733.

Eckert, R., and D. Lux (1976) A voltage-sensitive persistent calcium conductance in neuronal somata of Helix. J. Physiol. (Lond.) 254: 129-151.

Eckert, R., and D. Tillotson (1981) Calcium-mediated inactivation of the calcium conductance in caesium-loaded giant neurones of Aplysia californica. J. Physiol. (Lond.) 314: 265-280.

Frazier, W. T., E. R. Kandel, I. Kuffermann, R. Waziri, and R. E. Coggeshall (1967) Morphological and functional properties of identified neurons in the abdominal ganglion of Aplysia californica. $\mathrm{J}$. Neurophysiol. 30: 1288-1351.

Gola, M. (1974) Neurones à ondes-salves des mollusques. Variations cycliques lentes des conductances ioniques. Pfluegers Arch. 352: 1736.

Gorman, A. L. F., and M. V. Thomas (1980) Potassium conductance and internal calcium accumulation in a molluscan neuron. J. Physiol. (Lond.) 308: 287-313.

Gorman, A. L. F., A. Hermann, and M. V. Thomas (1982) Ionic requirements for membrane oscillations and their dependence on the calcium concentraton in a molluscan bursting pace-maker neurone. J. Physiol. (Lond.) 327: 185-217.

Johnston, D. (1980) Voltage, temperature, and ionic dependence of slow outward current in Aplysia burst-firing neurones. J. Physiol. (Lond.) 298: 145-157.
Kramer, R. H. (1984) The ionic mechanism of bursting pacemaker activity in Aplysia neurons. Ph.D. dissertation, University of California, Berkeley, CA.

Kramer, R. H., and R. S. Zucker (1985a) Calcium-dependent inward current in Aplysia bursting pace-maker neurones. J. Physiol. (Lond.) 362: 155-181,

Kramer, R. H., and R. W. Zucker (1985b) Calcium-induced inactivation of calcium current causes the inter-burst hyperpolarization of Aplysia bursting neurones. J. Physiol. (Lond.) 362: 131-160.

Lewis, D. V. (1984) Spike aftercurrents in R15 of Aplysia: Their relationship to slow inward current and calcium influx. J. Neurophysiol. 51: 387-403.

Meech, R. W. (1978) Calcium-dependent potassium activation in nervous tissues. Annu. Rev. Biophys. Bioeng. 7: 1-18.

Ruben, P., J. W. Johnson, and S. Thompson (1985) Analysis of FMRFamide effects on Aplysia bursting neurons. J. Neurosci. 6: 252-259.

Smith, S. J. (1978) The mechanism of bursting pacemaker activity in neurones of the mollusc Tritonia diomedia. Ph.D. dissertation, University of Washington, Seatle, WA.

Smith, S. J., and S. Thompson (1986) Slow membrane currents in bursting pacemaker neurones of Tritonia. J. Physiol. (Lond.) (in press).

Smith, S. J., and R. S. Zucker (1980) Aequorin response facilitation and intracellular calcium accumulation in molluscan neurones. $J$. Physiol. (Lond.) 300: 167-196.

Thomas, R. C. (1972) Electrogenic sodium pump in nerve and muscle cells. Physiol. Rev. 52: 563-594.

Thompson, S. H. (1976) Membrane currents underlying bursting in molluscan pacemaker neurons. Ph.D. dissertation, University of Washington, Seattle, WA.

Thompson, S. H. (1977) Three pharmacologically distinct potassium channels in molluscan neurones. J. Physiol. (Lond.) 265: 465-488.

Thompson, S. H., and S. J. Smith (1976) Depolarizing afterpotentials and burst production in molluscan pacenaker neurons. J. Neuruphysiol. 39: 153-161.

Tillotson, D. (1979) Inactivation of $\mathrm{Ca}$ conductance dependent on entry of $\mathrm{Ca}$ ions in molluscan neurons. Proc. Natl. Acad. Sci. USA 77: 1497-1500.

Tillotson, D., and R. Horn (1978) Inactivation without facilitation of calcium conductance in caesium-loaded neurones of Aplysia. Nature 273: 312-314.

Willows, A. O. D., D. A. Dorsett, and G. Hoyle (1973) The neuronal basis of behavior in Tritonia. I. Functional organization of the central nervous system. J. Neurobiol. 4: 207-237. 